$16^{\text {th }}$ International Conference on

AEROSPACE SCIENCES \& AVIATION TECHNOLOGY,

$\boldsymbol{A S A T}$ - 16 - May 26 - 28, 2015, E-Mail: asat@mtc.edu.eg Military Technical College, Kobry Elkobbah, Cairo, Egypt

Tel : +(202) 24025292 - 24036138, Fax: +(202) 22621908

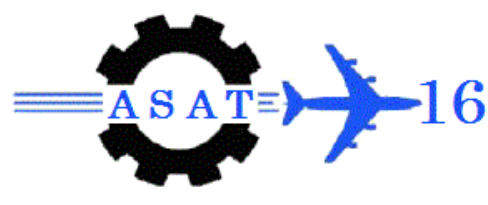

\title{
Numerical Study of Characteristics of Heat Transfer and Pressure Drop in Microchannels Using Nanofluid
}

I. Elbadawy ${ }^{* *}$, A. Anas*, M. Abd El-Rahman ${ }^{* * *}$

Department of Mechanical Power Engineering, Faculty of Engineering at El-Mattaria, Helwan University, Masaken El-Helmia P.O., Cairo 11718, Egypt

\begin{abstract}
The fluid flow and heat transfer characteristics in a three dimensional (3D) rectangular shaped microchannel heat sink (MCHS) with $\mathrm{Al}_{2} \mathrm{O}_{3}$-water nanofluids is numerically investigated. The thermal and flow fields are analyzed using different Reynolds numbers and nanoparticles with different concentrations. The 3D, steady, laminar flow and heat transfer governing equations are solved by finite volume method using ANSYS 14.0. The evaluating parameter such as temperature, heat transfer coefficient and pressure drop are obtained from the simulation. Results show enhanced performance with the usage of nanofluids, and slightly penalty in pressure drop. The increase in Reynolds number leads to increase in heat transfer rate as well as pressure drop and power.
\end{abstract}

\section{KEYWORDS}

Heat transfer, Microchannels, Heat sink, Numerical study, Nanofluid.

* Teaching Assistant, Department of Mechanical Power Engineering, Faculty of Engineering at ElMattaria, Helwan University, Masaken El-Helmia P.O., Cairo 11718, Egypt.

** Assistant Professor, Department of Mechanical Power Engineering, Faculty of Engineering at El-Mattaria, Helwan University, Masaken El-Helmia P.O., Cairo 11718, Egypt.

*** Associate Professor, Department of Mechanical Power Engineering, Faculty of Engineering at ElMattaria, Helwan University, Masaken El-Helmia P.O., Cairo 11718, Egypt. 


\section{NOMENCLATURE}

$\begin{array}{cl}A & \text { Area }\left(\mathrm{m}^{2}\right) \\ \mathrm{c}_{\mathrm{p}} & \text { Specific heat capacity }(\mathrm{J} / \mathrm{kg} \mathrm{k}) \\ \mathrm{D}_{\mathrm{h}} & \begin{array}{l}\text { hydraulic diameter of the fluid flow } \\ \text { channel }(\mathrm{m})\end{array} \\ \Delta \mathrm{h}_{\text {ine }} & \begin{array}{l}\text { Average heat transfer coefficient } \\ \text { increasing }(\mathrm{W} / \mathrm{m} . \mathrm{K})\end{array} \\ & \\ \mathrm{H} & \text { Height or thickness }(\mathrm{m}) \\ \mathrm{h}_{\mathrm{av}} & \text { Average heat transfer coefficient } \\ & \text { (W/m.K ) } \\ \mathrm{L} & \text { Channel length }(\mathrm{m}) \\ \mathrm{q} & \text { Heat flux }\left(\mathrm{W} / \mathrm{m}^{2}\right) \\ \mathrm{Re} & \text { Reynolds number } \\ \mathrm{u}_{\text {in }} & \text { Fluid inlet velocity (m/s) } \\ \mathrm{u}, \mathrm{v}, \mathrm{w} & \text { Velocity in } \mathrm{x}, \mathrm{y}, \text { and } \mathrm{z} \text { direction } \\ \mathrm{x}, \mathrm{y}, \mathrm{z} & \text { Cartesian coordinates } \\ \mathrm{T} & \text { Temperature }(\mathrm{K}) \\ \mathrm{W} & \text { Width }(\mathrm{m})\end{array}$

Greek Symbols

P density $\left(\mathrm{kg} / \mathrm{m}^{3}\right)$

$\begin{array}{cl}\mu & \text { Dynamic viscosity }(\mathrm{kg} / \mathrm{m} \mathrm{s}) \\ \mathrm{K} & \text { Thermal conductivity }(\mathrm{W} / \mathrm{m} \mathrm{K}) \\ \Phi & \text { Particle volume fraction } \\ \text { Subscript } \\ \text { av } & \text { Average } \\ \text { F } & \text { fluid } \\ \text { Nf } & \text { nanofluid } \\ \text { p } & \text { solid particles } \\ \text { b } & \text { bulk } \\ \text { j } & \text { Directions }(\mathrm{x}, \mathrm{y}, \mathrm{z}) \\ \mathrm{I} & \text { Directions }(\mathrm{x}, \mathrm{y}, \mathrm{z}) \\ \mathrm{Ch} & \text { Channel } \\ \mathrm{In} & \text { Inlet } \\ \text { Out } & \text { Outlet } \\ \text { Th } & \text { Thermocouple location } \\ \mathrm{t} & \text { Top thickness } \\ \mathrm{U} & \text { Unit cell } \\ 0 & \text { At inlet } \mathrm{x}=0\end{array}$

\section{INTRODUCTION}

Due to the higher generation of heat in the electronic chips, there have been widely using liquid cooling systems for their own safety considerations. But, the developing technology requires more effective coolant for these systems. The invention of nanofluid has promised to enhance the effectiveness of the new liquid coolant [1]. The suspension of nano-scaled particles (up to $100 \mathrm{~nm}$ ) to the base fluid is generally defined as a nanofluid. The mixture of solid particles to the liquid generally increases the thermal conductivity of the liquid because of its higher thermal conductivity itself. Miniaturization of the heat sink is another technique to increase the cooling efficiency of the cooling system. Since last two decades, there have been committed a lot of numerical, analytical and a few experimental investigation of nanofluids performances applying to the miniaturized heat sink for cooling of electronics [27].

Keblinski et al. [8] investigated the thermal transportation of nanofluids. They reported that a layer of liquid cluster around the nanoparticle had significant effects to increase the thermal conductivity of the nanofluids. It is also reported that the Brownian motion did not play a vital role to improve the thermal transportation of the nanofluids. While, Tokit et al. [9] mentioned that the Brownian motion has an important role to enhance the thermal conductivity by helping the cluster formation of the nanoparticle at a lower motion itself. Putra et al. [10] studied $\mathrm{Al}_{2} \mathrm{O}_{3}$-water and $\mathrm{TiO}_{2}$-water nanofluids for cooling of electronic chips. The necessity to develop a new cooling technique for microchip cooling instead of conventional technique was discussed in the study. A significant improvement in heat rejection from the electronic chip using nanofluid was obtained. Das et al. [11] inspected the effects of temperature on the heat transfer performances of nanofluids. At 4 vol. $\%$ concentration of $\mathrm{CuO}-\mathrm{H}_{2} \mathrm{O}$, increasing the temperature from 21 to $51 \mathrm{C}$. Also, it is observed that the thermal conductivity went up from $14 \%$ to $36 \%$, respectively. Nguyen et al. [12] experimentally studied the enhancement of heat transfer coefficient of $\mathrm{Al}_{2} \mathrm{O}_{3}-\mathrm{H}_{2} \mathrm{O}$ nanofluid compared to the pure water. About $40 \%$ 
increase in the heat transfer coefficient using 6.8 vol.\% of nanoparticle was obtained. The lower particle size of nanoparticles leaded to better thermal performances compared to the large particle size. The heat transfer enhancement using $\mathrm{Al}_{2} \mathrm{O}_{3}-\mathrm{H}_{2} \mathrm{O}$ nanofluid in a commercial water block was studied by Selvakumar and Suresh [13]. They reported about $20 \%$ improvement in the conductance using $20-30 \mathrm{~nm}$ alumina nanofluid compared to the deionized water. A little increment on pumping power with the nanofluids was also mentioned. Whelan et al. [14] designed and investigated a tube array remote heat exchanger for CPU cooling. It is successfully obtained a suitable base temperature and a lower thermal resistance.

Recently, the MCHS has become a very good topic to attract the researcher's attention. The application of nanofluids to microchannel heat sink has offered significant cooling performances for cooling of electronics. Ho and Chen [15] performed an experiment on MCHS using $\mathrm{Al}_{2} \mathrm{O}_{3}-\mathrm{H}_{2} \mathrm{O}$ nanofluid. A very high improvement in heat transfer coefficients using nanofluid compared to the pure water was obtained. Tullius and Bayazitoglu [16] also studied the influence of $\mathrm{Al}_{2} \mathrm{O}_{3}-\mathrm{H}_{2} \mathrm{O}$ nanofluid on enhancing the heat transfer performance of the circular fin structured MCHS. The nanofluid showed a great enhancement in thermal transportation. In the same time, a little surface imperfection problem occurred because of the nanoparticle sedimentation, which was responsible for reducing the heat transfer performances. The heat transfer characteristics using $\mathrm{TiO}_{2}-\mathrm{H}_{2} \mathrm{O}$ nanofluid in a rectangular minichannel were also experimentally investigated by Naphon and Nakharintr [17]. A significant enhancement in thermal performance without increasing the pumping power was achieved. Keshavarz et al. [18] numerically investigated the nanofluids cooling effects and the pressure drop across the MCHS. After getting satisfactory results compared to the other available analysis, a contextual connection for Nusselt number and friction factor was suggested.

It should be noted from the above literature review, however, that limited studies are available on nanofluid flow and heat transfer characteristics of rectangular shaped MCHS performance and this has motivated the present study. Thus, the present study deals with 3D numerical simulations of laminar flow and heat transfer characteristics of rectangular shaped MCHS using $\mathrm{Al}_{2} \mathrm{O}_{3}$-water nanofluid with volume fraction ranged from $1 \%$ to $5 \%$, Reynolds number ranged from 200 to 1500 , and the heat flux, $\mathrm{q}=100 \mathrm{~W} / \mathrm{cm}^{2}$. Results of interests such as temperature distribution, heat transfer coefficient and pressure drop are the key parameters to illustrate the effects of nanofluid volume fraction and Reynolds number on MCHS performance.

\section{MATERIALS AND METHODS}

\section{Description of the Design Cooling Model}

The three-dimensional fluid flow and heat transfer in a rectangular copper MCHS were analyzed using water and $\mathrm{Al}_{2} \mathrm{O}_{3}$-water nanofluid as the cooling fluid. Figure 1 shows a schematic structure and main dimensions of a rectangular MCHS. The dimensions are listed in Table 1. 
Table 1. Dimensions of MCHS unit cell.

\begin{tabular}{lc}
\hline Parameters & Values [mm] \\
\hline Channel width $\left[\mathrm{W}_{\mathrm{ch}}\right]$ & 0.2 \\
Channel height $\left[\mathrm{H}_{\mathrm{ch}}\right]$ & 0.7 \\
Channel length $[\mathrm{L}]$ & 44.764 \\
Unit cell width $\left[\mathrm{W}_{\mathrm{u}}\right]$ & 0.467 \\
Half-width of wall separating channels [Ws] & 0.118 \\
Unit cell height $[\mathrm{H}]$ & 19.05 \\
Cover plate thickness $\left[\mathrm{H}_{\mathrm{t}}\right]$ & 12.7 \\
Thickness from unit cell bottom wall to channel bottom & 4.637 \\
wall $\left[\mathrm{H}_{\mathrm{B}}\right]$ & \\
Thermocouple plane height $\left[\mathrm{H}_{\mathrm{th}}\right]$ & 3.175 \\
\hline
\end{tabular}

\section{Governing Equation}

Following Elbadawy et al. [19], the assumptions used in this study is indicated in Table 2. According to these assumptions the conservation mass, momentum and energy equations, respectively are as follows

$$
\begin{aligned}
& \frac{\partial}{\partial \mathrm{x}_{\mathrm{i}}}\left(\rho \mathrm{u}_{\mathrm{i}}\right)=0 \\
& \frac{\partial}{\partial \mathrm{x}_{\mathrm{i}}}\left(\rho \mathrm{u}_{\mathrm{i}} \mathrm{u}_{\mathrm{j}}\right)=-\frac{\partial \mathrm{p}}{\partial \mathrm{x}_{\mathrm{j}}}+\frac{\partial}{\partial \mathrm{x}_{\mathrm{i}}}\left(\mu \frac{\partial \mathrm{u}_{\mathrm{j}}}{\partial \mathrm{x}_{\mathrm{i}}}\right)+\frac{\partial}{\partial \mathrm{x}_{\mathrm{i}}}\left(\frac{\partial \mathrm{u}_{\mathrm{i}}}{\partial \mathrm{x}_{\mathrm{j}}}\right), \mathrm{j}=1,2,3 \\
& \frac{\partial}{\partial \mathrm{x}_{\mathrm{i}}}\left(\rho \mathrm{u}_{\mathrm{i}} \mathrm{T}\right)=\frac{\partial}{\partial \mathrm{x}_{\mathrm{i}}}\left[\left(\frac{\mathrm{\kappa}}{\mathrm{c}_{\mathrm{p}}}\right) \frac{\partial \mathrm{T}}{\partial \mathrm{x}_{\mathrm{i}}}\right]
\end{aligned}
$$

Table 2. Assumptions

\begin{tabular}{ll}
\hline Parameters & Assumptions \\
\hline Flow characteristics & $\begin{array}{l}\text { Three dimensions, steady, incompressible, laminar and } \\
\text { single phase }\end{array}$ \\
Body force & Neglected \\
Fluid properties & Constant and viscous dissipation is neglected \\
No slip boundary condition & $\mathrm{u}=\mathrm{v}=\mathrm{w}=0$ at solid wall [20, 21] \\
Inlet velocity & Uniform [20, 21] \\
Microchannels & Identical in heat transfer and flow characteristics \\
& (one channel can be investigated) [22] \\
\hline
\end{tabular}

The boundary conditions for the computational study, indicated in Fig. 1, were provided via experimental data of $\mathrm{Qu}$ and Mudawar [23]. At the channel inlet $(\mathrm{x}=0)$ the velocity is determine for each Re. The flow inters the channel at $288 \mathrm{k}$ the governing systems of equations described above were solved using the commercial CFD package, ANSYS [FLUENT] 14.0.

\section{Thermophysical Properties of Nanofluids}

The thermophysical properties of the nanofluids were assumed constant due to small variations with the temperature range tested. These properties mainly depend upon the properties of the base fluid and the solid particles, volume fraction of the solid particles in the suspension and particles shape. The properties of nanofluids can be calculated using the following relations [24].

Thermal conductivity 


$$
k_{n f}=\left[\frac{k_{p}+(n-1) k_{b f}-(n-1) \varphi\left(k_{b f}-k_{p}\right)}{k_{p}+(n-1) k_{b f}+\varphi\left(k_{b f}-k_{p}\right)}\right] k_{b f}
$$

where $\mathrm{n}$ is solid particle shape factor ( $\mathrm{n}=3$ for spherical particles).

\section{Dynamic viscosity:}

$$
\frac{\mu_{\mathrm{nf}}}{\mu_{\mathrm{bf}}}=1+2.5 \varphi
$$
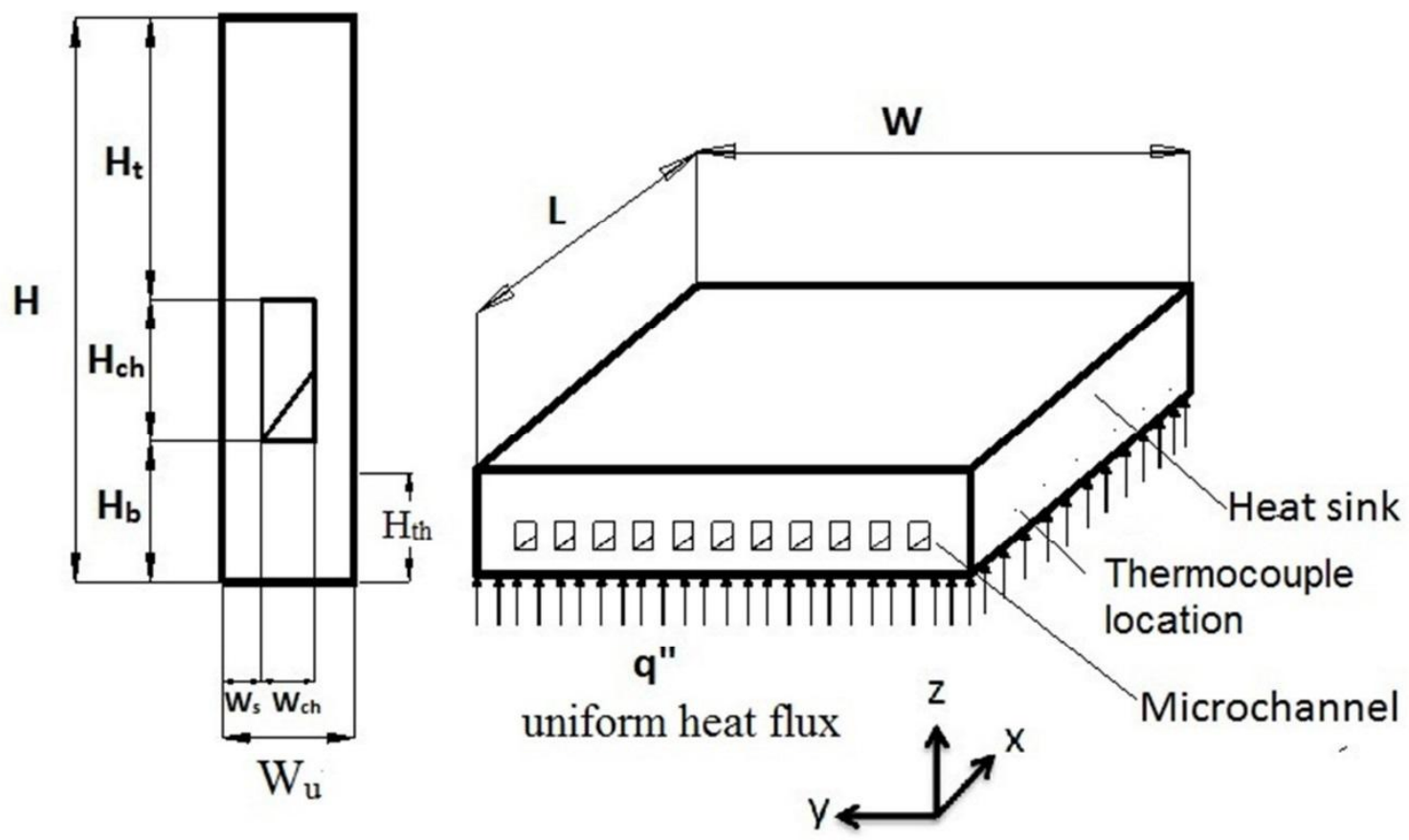

Fig. 1: Schematic of the microchannel heat sink [19].

\section{Density:}

$$
\rho_{\mathrm{nf}}=(1-\varphi) \rho_{\mathrm{bf}}+\varphi \rho_{\mathrm{p}}
$$

Heat capacity:

$$
c_{p_{\text {nf }}}=(1-\varphi) c_{p_{b f}}+\varphi c_{p_{p}}
$$

where $\varphi$ is particle volume fraction, the subscript "nf" refers to nanofluid, "bf" refers to base fluid, and " $p$ " refers to particle. According to the nanoparticle volume fraction used in the current study, the thermophysical properties as listed in Table 3. 
Table 3. Thermophysical properties of $\mathrm{Al}_{2} \mathrm{O}_{3}$ nanoparticles, water, and $\mathrm{Al}_{2} \mathrm{O}_{3}$-water nanofluid at $288 \mathrm{~K}$. [25]

\begin{tabular}{cccccc}
\hline Properties & $\begin{array}{c}\text { Nanoparticle } \\
\text { (Alumina) }\end{array}$ & $\begin{array}{c}\text { Base fluid } \\
\text { (Water) }\end{array}$ & \multicolumn{3}{c}{ Nanofluid (alumina-water) } \\
\cline { 4 - 6 } & & & $\varphi=0.01$ & $\varphi=0.03$ & $\varphi=0.05$ \\
\hline$\rho\left(\mathrm{kg} / \mathrm{m}^{3}\right)$ & 3970 & 1000 & 1029.7 & 1089.1 & 1148.5 \\
$\mathrm{c}_{\mathrm{p}}(\mathrm{J} / \mathrm{kg} \mathrm{K})$ & 765 & 4183 & 4148.82 & 4080.46 & 4012.1 \\
$\kappa(\mathrm{W} / \mathrm{m} \mathrm{k})$ & 36 & 0.6 & 0.6172936 & 0.652897227 & 0.689923793 \\
$\mu(\mathrm{kg} / \mathrm{m} \mathrm{s})$ & & 0.001003 & 0.001028075 & 0.001078225 & 0.001128375 \\
\hline
\end{tabular}

\section{RESULTS AND DISCUSSION}

The governing equations associated with the boundary conditions were solved numerically using the finite volume method. A second order upwind scheme was used to discretize the convection terms in pressure, momentum and energy equations. Before carrying out the whole simulation work with FLUENT, a grid independent study was investigated. According to the suitable mesh size obtained [19], the accuracy of results was verified by comparison the current computational results with the available data published by Qu and Mudawar [23]. The experimental model presented in [23] was a rectangular MCHS with hydraulic diameter 348.9 $\mu \mathrm{m}$, channel height $713 \mu \mathrm{m}$, channel width $231 \mu \mathrm{m}$ and length $44.764 \mathrm{~mm}$. Qu and Mudawar measured the temperature in four points along the channel bottom wall at height of $3175 \mu \mathrm{m}$, $\mathrm{Re}=890$, inlet temperature of $288 \mathrm{k}$ and constant heat flux of $100 \mathrm{~W} / \mathrm{cm}^{2}$.

The mesh investigation is one the important steps in the simulation. It concerned with the type and the sizes of the mesh intervals. The best size was selected according to comparison done between the three sizes results.Accordingly, three different levels of cell volume are used (20, 40 and $60 \mathrm{~m}^{3}$ ). It is found that the maximum percentage change in result is $1.5 \%$. Therefore, the largest size is chosen to save the computing time as shown in figure 2.

Figure 3 shows the comparison between results of present numerical model and the experimental data [23] for local temperature distribution along the thermocouple plane (xyplane). It can be seen that, the agreement between numerical and experimental results is acceptable. Therefore, the present numerical model is reliable and can be used to study the effect of using nanofluid as a coolant on the performance of a MCHS.

The generated heat in electronic components whenever electric current flows through them causes their temperatures to rise. In order to minimize the temperature rise of the components, the dissipation of heat with a high rate is necessary for their proper functioning. According to literature review, nanofluids have a significant effect on cooling process. As a result, this study was carried out using Al2O3-water nanofluid with volume fraction ranged from $1 \%, 3 \%$ and 5\% at Reynolds number ranged from 200 to 1500 and constant heat flux of $100 \mathrm{~W} / \mathrm{cm}^{2}$. The series CFD results present the influence of these parameters on temperature and heat transfer coefficient distribution along line in $\mathrm{x}$-direction at $\mathrm{H}_{\mathrm{th}}=3175 \mu \mathrm{m}$. 


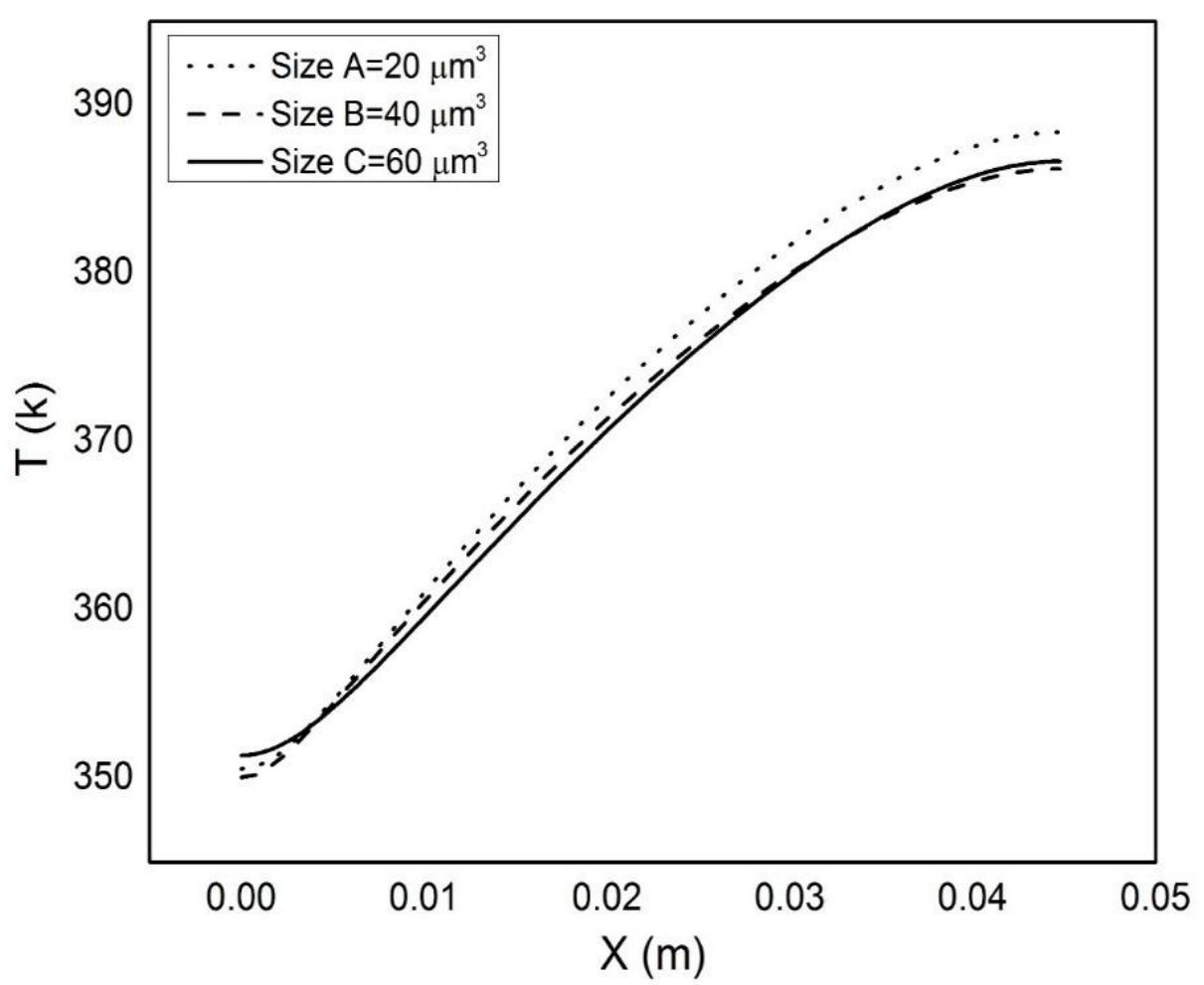

Fig.2: Comparison between three different levels of cell volume.

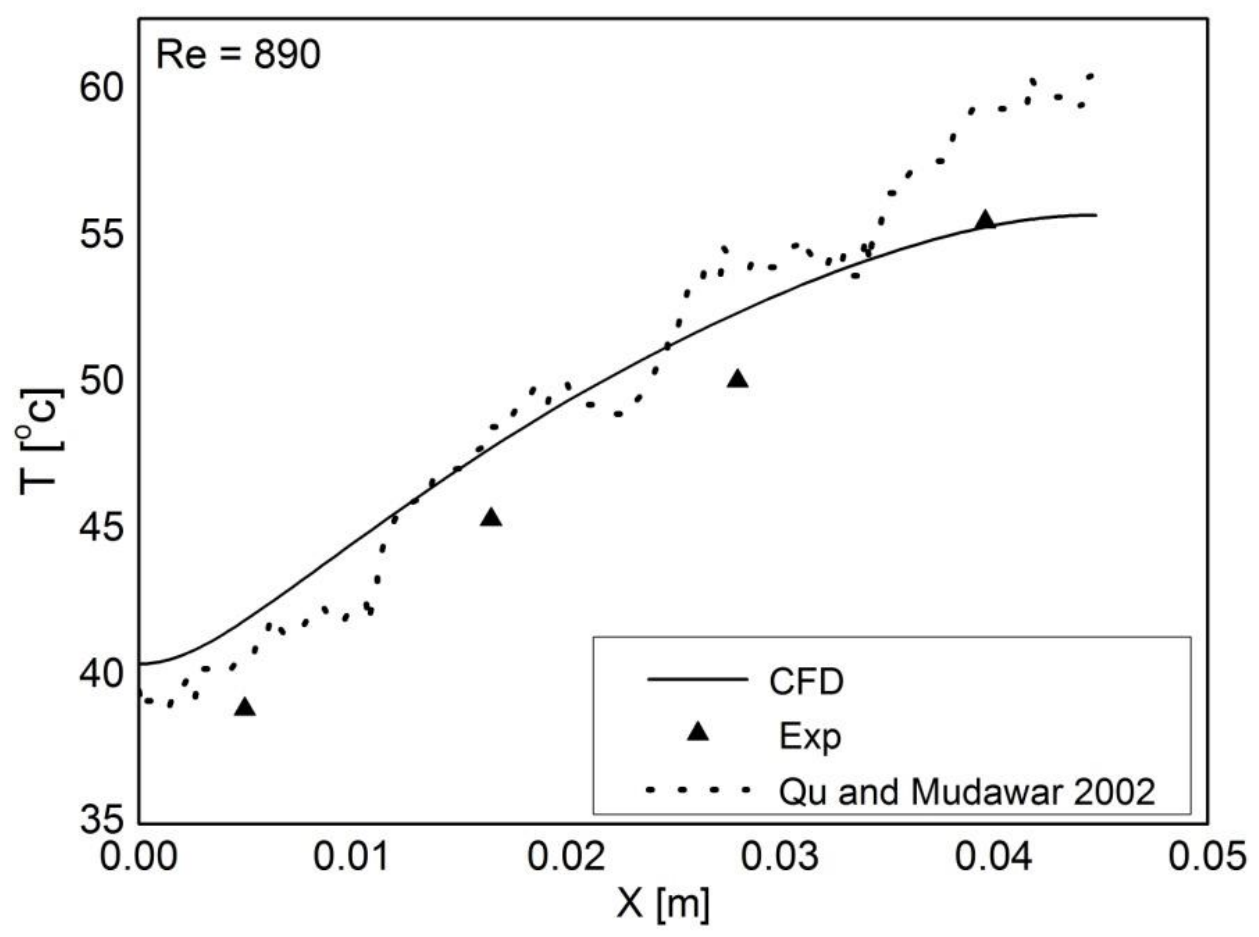

Fig. 3: Comparison of experimental and computational data [23] and current prediction CFD results for temperature distribution along line in $\mathrm{x}$-direction at $\mathrm{q}^{\prime}=100 \mathrm{~W} / \mathrm{cm}^{2}$ and $\mathrm{Re}=890$.

The hydraulic diameter " $\mathrm{D}_{\mathrm{h}}$ " of the fluid flow channel, Reynolds number "Re", the average heat transfer coefficient " $h$ " and bulk temperature " $\mathrm{T}_{\mathrm{b}}$ " are calculated as follows [26]

$$
D_{h}=\frac{4 A}{p}=\frac{4 W_{c h} H_{c h}}{2\left(W_{c h+} H_{c h}\right)}
$$




$$
\begin{aligned}
& \operatorname{Re}=\frac{\rho u_{\text {in }} \mathrm{D}_{\mathrm{h}}}{\mu} \\
& \mathrm{h}_{\text {avg }}=\frac{\mathrm{q}^{\mathrm{s}}}{\left(\mathrm{T}_{\mathrm{g}}-\mathrm{T}_{\mathrm{b}}\right)} \\
& \mathrm{T}_{\mathrm{b}}=\frac{\mathrm{T}_{\text {in }}+\mathrm{T}_{\text {out }}}{2}
\end{aligned}
$$

The effect of particles volume fraction " $\varphi$ " was investigated computationally. Figure 4 depicts the effect of $\varphi$ on the temperature distribution and the average heat transfer coefficient " $h_{a v}$ " which was calculated and based on the bottom wall of channel. Generally, it indicates that the influence of $\varphi$ is significant and that increasing $\varphi$ may provide a noticeable cooling enhancement in the temperature comparatively to pure water due to increase nanofluid thermal conductivity (Eq.(4)). In more detail, the average heat transfer coefficients are maximum at channel entrance and sharply decrease up to $\mathrm{X} / \mathrm{L}=0.2$ which represents the developing region as shown in the Figure 4 (b). This is due to very thin local boundary layer that grows up along the entrance length. For this reason, the temperature, shown in Figure 4(a), significantly increases along the channel at the water inlet while the temperate increase rate decreases at $\mathrm{X} / \mathrm{L}>0.2$ due to growing boundary layer thickness.
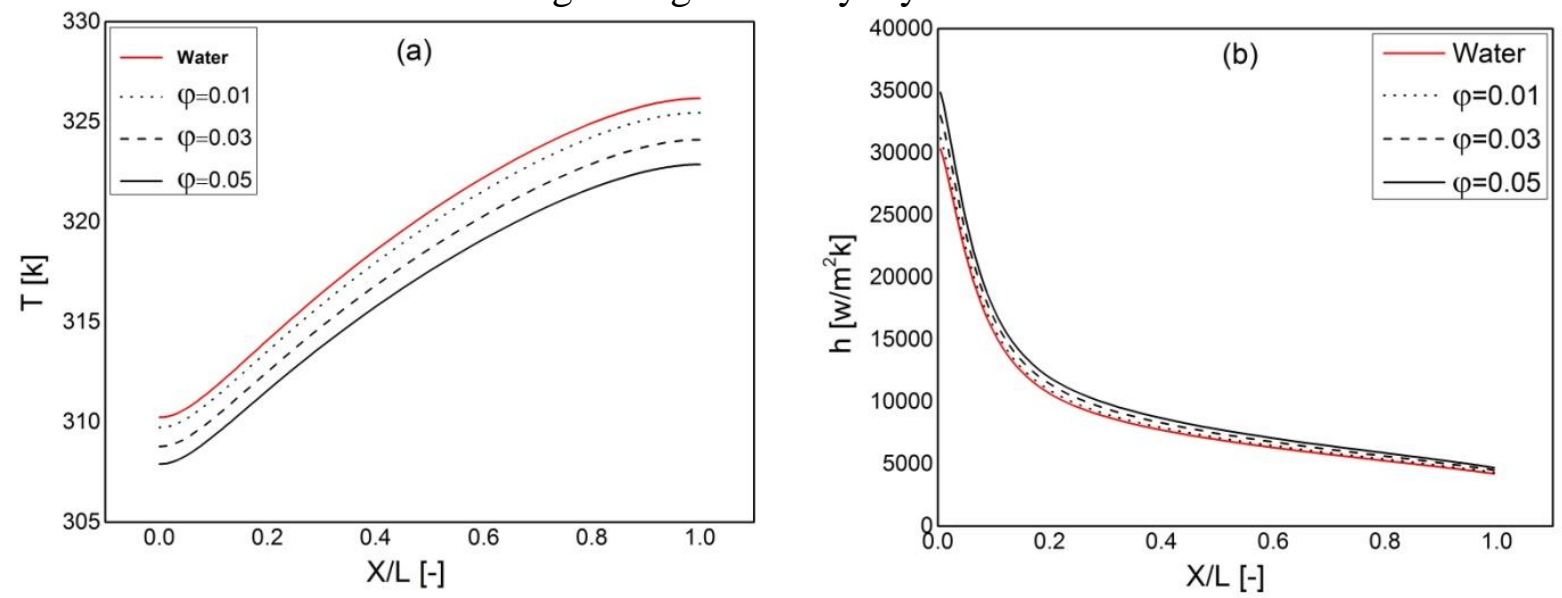

Fig.4: Effect of particles volume fraction " $\varphi$ " on (a) local temperature distribution along the channel (x-direction) and (b) average heat transfer coefficient based on the bottom wall at

$$
\mathrm{Re}=800 \text {. }
$$

The local temperature distribution at $\mathrm{x}-\mathrm{y}$ thermocouple plane, $\operatorname{Re}=800$ and different $\varphi$ is illustrated in Fig. 5. Some interesting results are readily observed. The temperature increases along the longitudinal $\mathrm{x}$-direction from the channel inlet to the channel outlet due to increase the coolant fluid temperature. It is very clear that the inlet and outlet temperature decrease with increasing the volume fraction.

Figure 6 shows the local temperature distribution in $\mathrm{x}-\mathrm{z}$ plane for different $\varphi$. The temperature variations are represented by variations in color, with temperature scale located at the side of each figure. The figure gives detailed information about the enhancement of cooling process due to high particle concentration.

Figure 7 (a) shows the temperature reduction " $\Delta \mathrm{T}_{\text {rad" }}$ " which represents the difference between the average temperature on the thermocouple $x-y$ plane using pure water and the average temperature on the same plane using nanofluid for different $\varphi$ and different Re. At constant nanoparticles volume fraction, the temperature reduction decreases with increasing Reynolds number due to the dominating effect of velocity. For the same Reynolds number, the 
temperature reduction increases with increasing the volume fraction. As a result, the heat sink temperature decreases with increasing the volume fraction of nanoparticles.

Figure 7 (b) represents the increasing in the average heat transfer coefficient " $\Delta \mathrm{h}_{\text {inc }}$ " which represents the difference between the average heat transfer coefficient on the channel bottom using pure water and the average heat transfer coefficient on the same plane using nanofluid for different $\varphi$ and different Re . At constant volume fraction, increased Reynolds number leads to significant increasing in $\Delta \mathrm{h}_{\text {inc }}$. Also, at constant Reynolds number, increased volume fraction enhances significantly the heat transfer coefficient comparing with that of pure water. For example, at $\mathrm{Re}=800$ the heat transfer coefficient enhancement for $\varphi=1 \%, 3 \%$ and $5 \%$ increases by approximately 270,812 and 1360 (W/m.K), respectively.

Figure 8 shows the values of the pressure drop versus Reynolds number for various volume fractions of nanoparticles. It is observed that by increasing both $\operatorname{Re}$ and $\varphi$, the pressure drop increases. Nanofluid indicated higher pressure drop compared with the base fluid, especially at high Reynolds number. Obviously, friction factor increases with increasing in concentration of nanoparticles due to the rise of working fluid viscosity (Eq. (5)).

\section{CONCLUSION}

A computational model was utilized to simulate a three dimensional fluid flow and heat transfer in a 3D MCHS filled with $\mathrm{AL}_{2} \mathrm{O}_{3}$-water nanofluid. Based on the present computational study, the following results are obtained:

- For all values of nanoparticles volume fractions, the temperature of the coolant fluid and MCHS increase along the channel length;

- Addition of nanoparticles slightly increases the heat transfer coefficient and significantly decreases the MCHS temperature compared with that of the pure water. Therefore, nanofluids could be a promising replacement for pure water in MCHS;

- The pressure drop increases by increasing Reynolds number and nanoparticles volume fraction as well as the required power;

- Using nanofluids compared to the base fluid "water" leads to increase in the pressure drop.
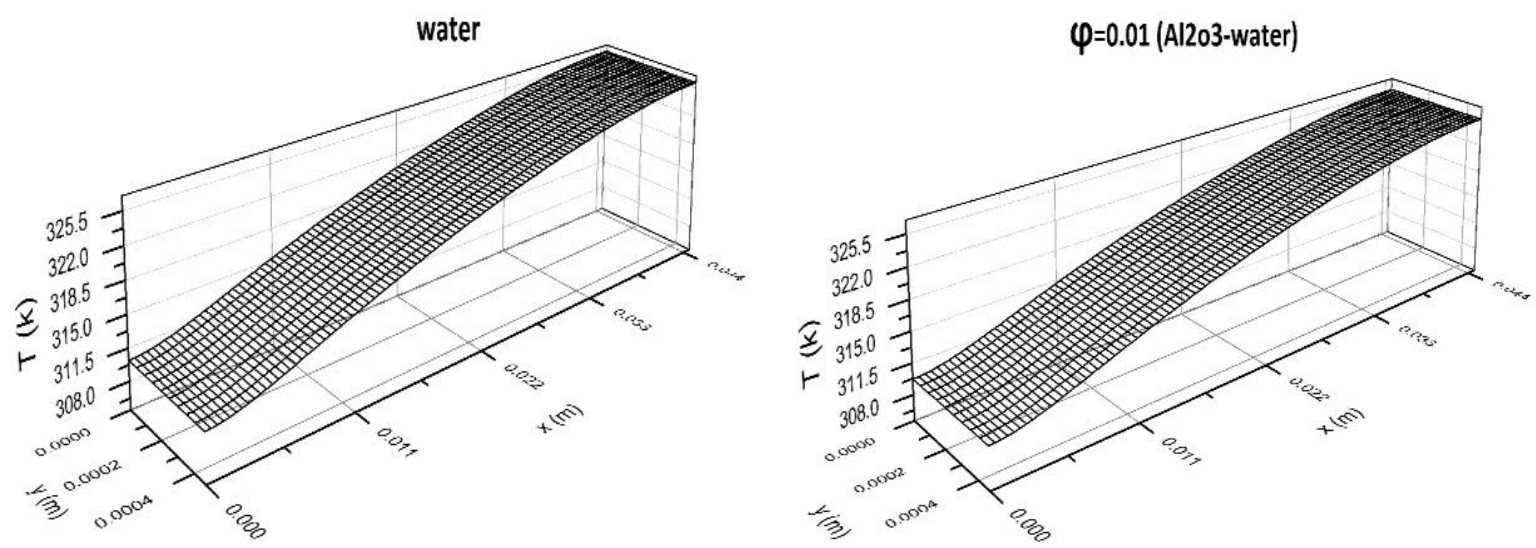

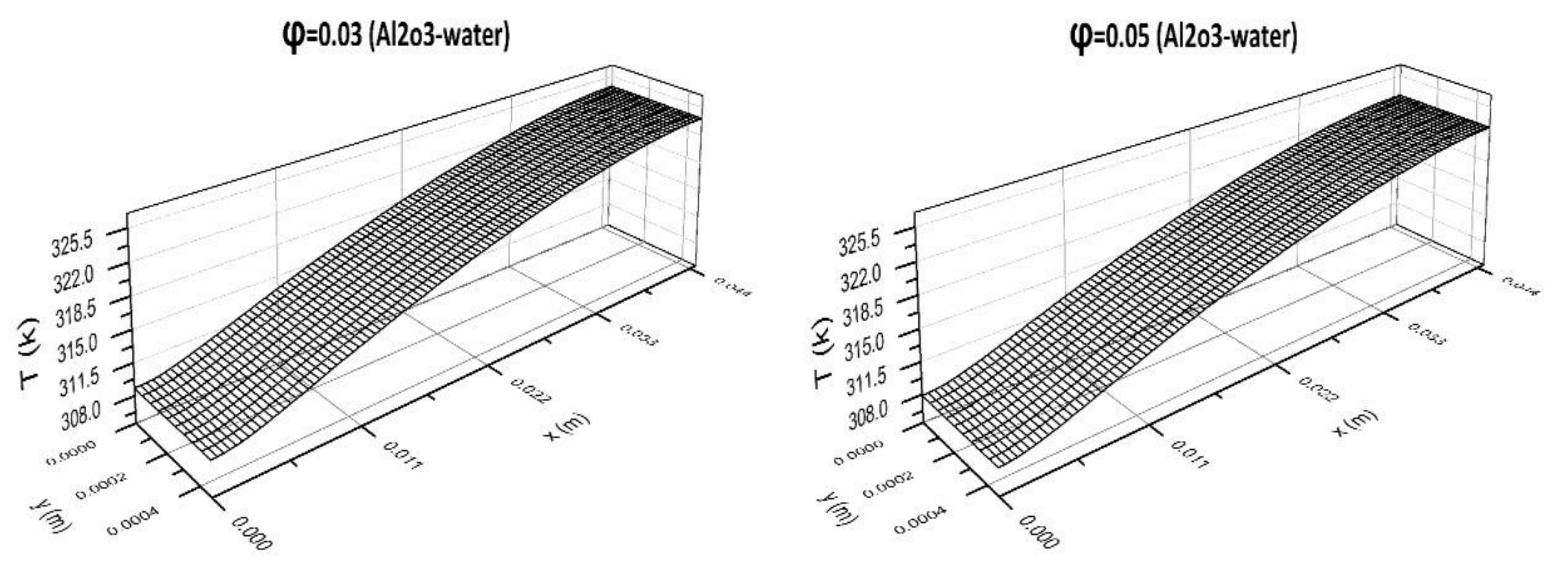

Fig.5: Local temperature distribution along x-y thermocouple plane at different $\varphi$ and

$$
\operatorname{Re}=800 .
$$
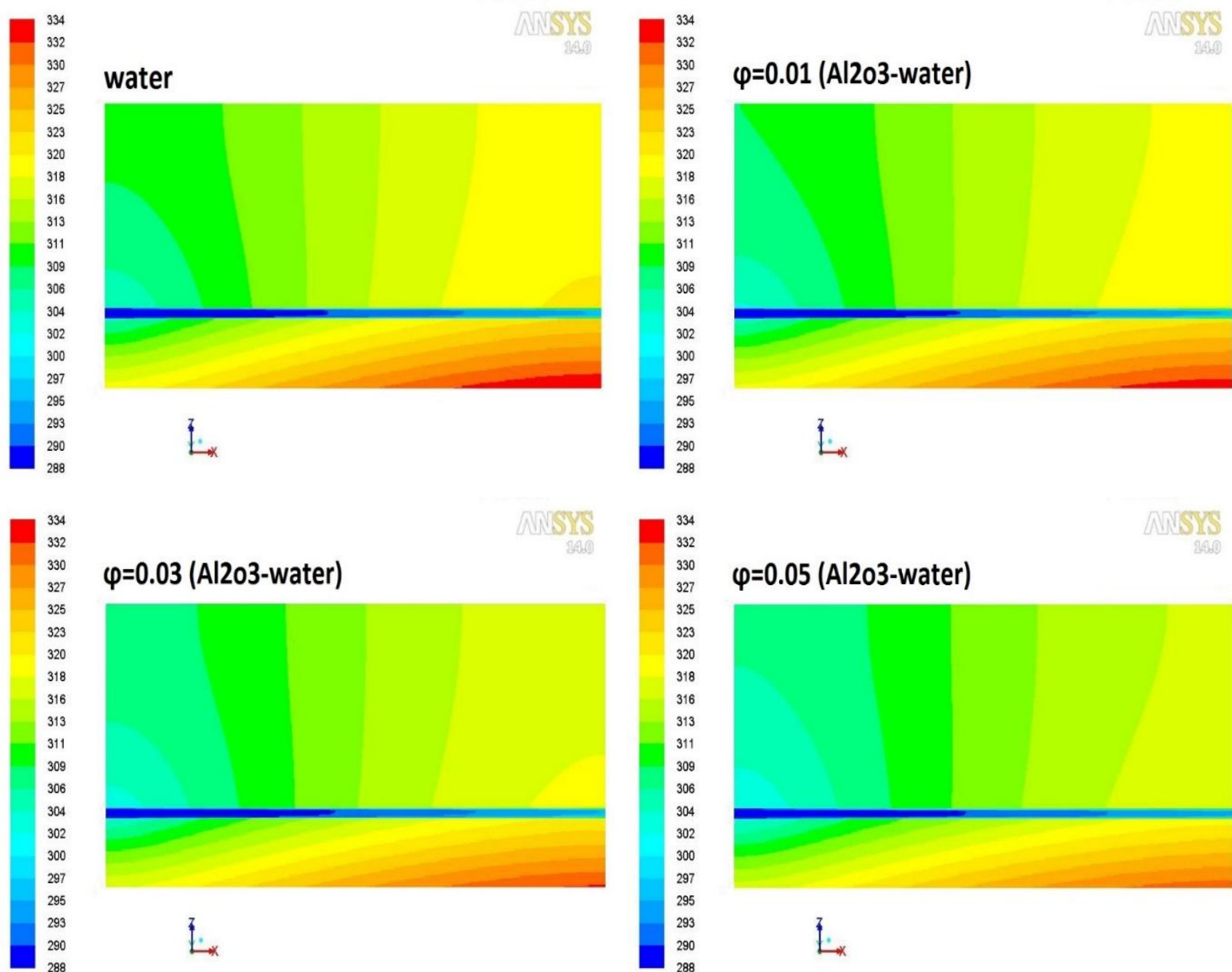

$\varphi=0.05$ (Al203-water)
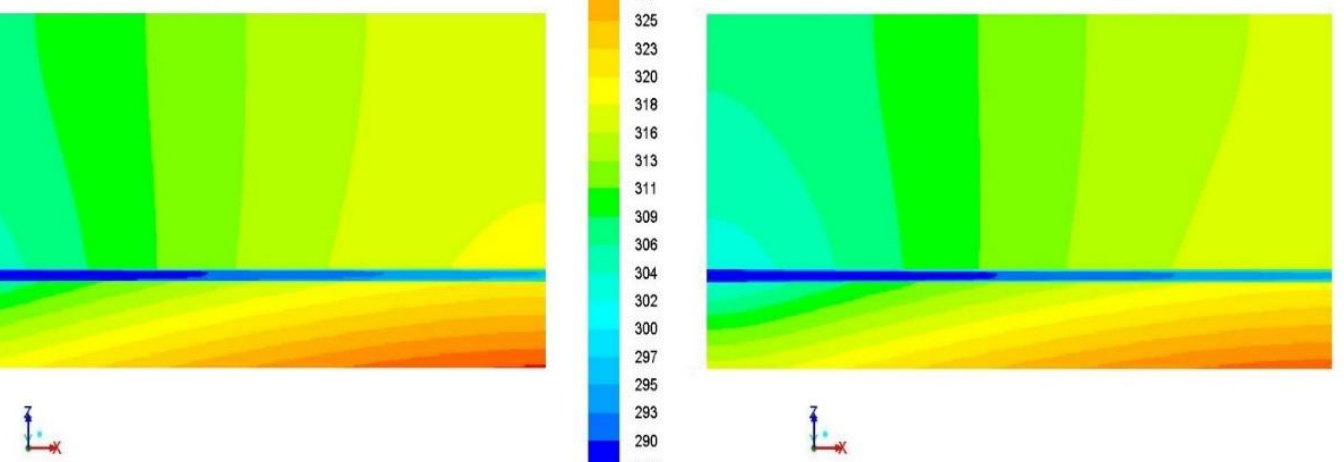

Fig.6: Local temperature distribution contours in $\mathrm{x}-\mathrm{z}$ plane at different $\varphi$ and $\operatorname{Re}=800$. 

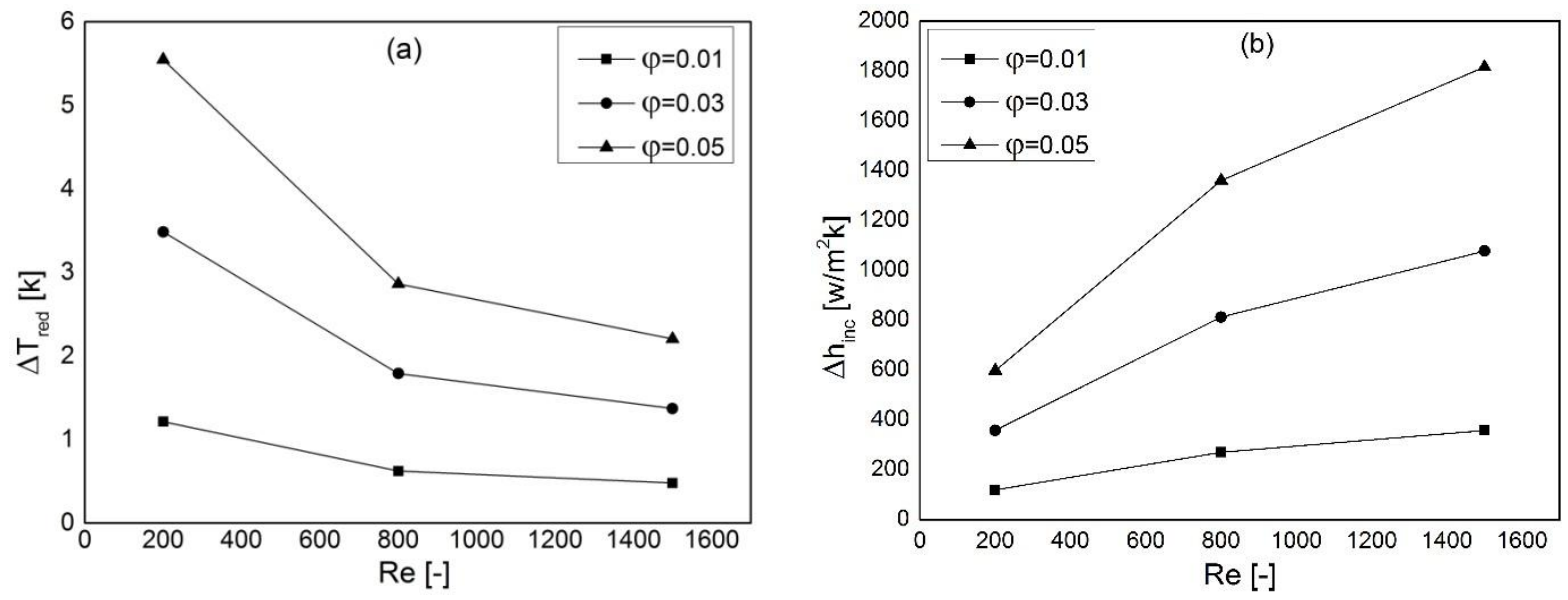

Fig.7: (a) Temperature reduction and (b) average heat transfer coefficient increasing at different $\varphi$ and Re.

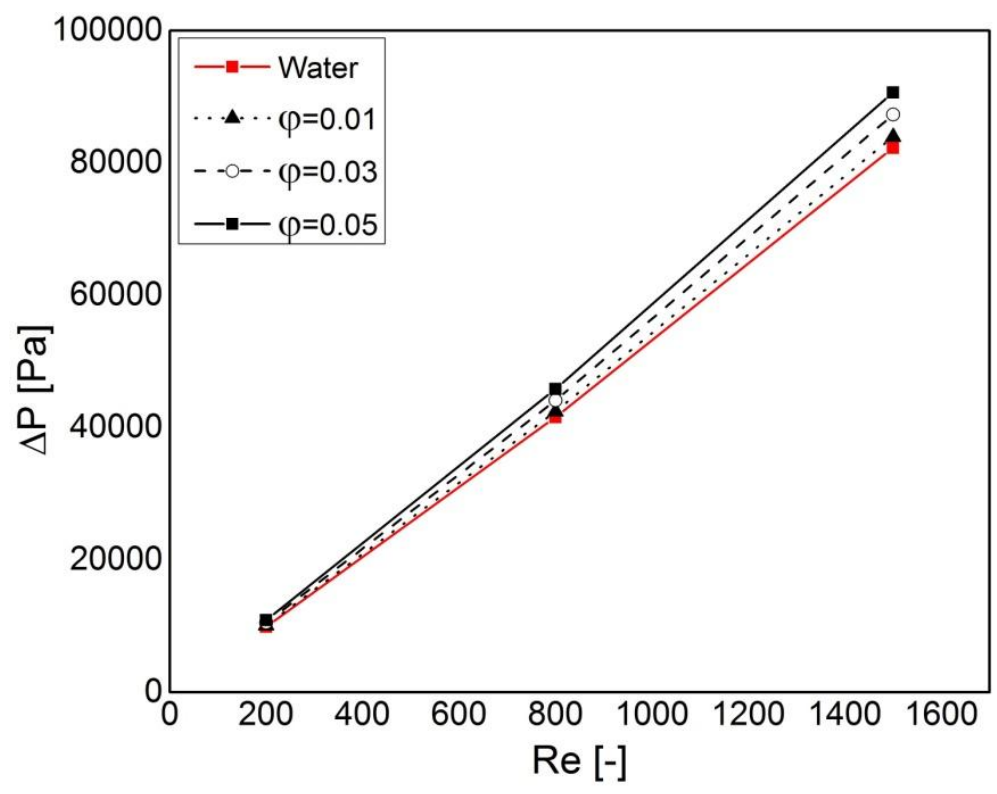

Fig.8: Pressure drop at different $\varphi$ and Re.

\section{REFERENCES}

[1] S.U.S. Choi and J.A. Eastman, "Enhancing thermal conductivity of fluids with nanoparticles", in: Conference: 1995 International Mechanical Engineering Congress and Exhibition, San Francisco, CA, United states, 12-17 November, ASME, San Francisco, 1995, pp. 99-105.

[2] L. Godson, B. Raja, D. Mohan Lal and S. Wongwises, "Enhancement of heat transfer using nanofluids", an overview, Renew. Sustain. Energy Rev. 14, 2010, 629-641. 
[3] B.H. Salman, H.A. Mohammed and A.S. Kherbeet, "Heat transfer enhancement of nanofluids flow in microtube with constant heat flux", Int. Commun. Heat Mass Transfer 39, 2012, 1195-1204.

[4] S. Lee and S.U.S. Choi, "Application of metallic nanoparticle suspensions in advanced cooling systems, Recent Advances in Solid/Structures and Applications of Metallic Materials", PVP vol. 342/MD-vol 72, ASME, New York, 1996, pp. 227-234.

[5] A. Asthana, I. Zinovik, C. Weinmueller and D. Poulikakos, "Significant Nusselt number increase in microchannels with a segmented flow of two immiscible liquids: an experimental study", Int. J. Heat Mass Transfer 54 ,2013, 1456- 1464.

[6] E.M. Tokit, H.A. Mohammed and M.Z. Yusoff, "Thermal performance of optimized interrupted microchannel heat sink (IMCHS) using nanofluids", Int. Commun. Heat Mass Transfer39, 2013, 1595-1604.

[7] M.R. Sohel, R. Saidur, M.F.M. Sabri, M. Kamalisarvestani, M.M. Elias and A. Ijam, "Investigating the heat transfer performance and thermophysical properties of nanofluids in a circular micro-channel”, Int. Commun. Heat Mass Transfer 42, 2013, $75-81$.

[8] P. Keblinski, J.A. Eastman and D.G. Cahill, "Nanofluids for thermal transport", Mater. Today 8, 2013, 36-44.

[9] E. Mat Tokit, M.Z. Yusoff and H.A. Mohammed, "Generality of Brownian motion velocity of two phase approach in interrupted microchannel heat sink", Int. Commun. Heat Mass Transfer 49, 2013, 128-135.

[10] N. Putra, Yanuar and F.N. Iskandar, "Application of nanofluids to a heat pipe liquidblock and the thermoelectric cooling of electronic equipment", Exp. Therm. Fluid Sci. 35, 2011, 1274-1281.

[11] S.K. Das, N. Putra, P. Thiesen and W. Roetzel, "Temperature dependence of thermal conductivity enhancement for nanofluids”, J. Heat Transfer 125, 2003, 567-574.

[12] C.T. Nguyen, G. Roy, C. Gauthier and N. Galanis, "Heat transfer enhancement using $\mathrm{Al}_{2} \mathrm{O}_{3}$-water nanofluid for an electronic liquid cooling system", Appl. Therm. Eng. 27, 2007, 1501-1506.

[13] N.A. Roberts and D.G. Walker, "Convective performance of nanofluids in commercial electronics cooling systems”, Appl. Therm. Eng. 30, 2010, 2499- 2504.

[14] B.P. Whelan, R. Kempers and A.J. Robinson, "A liquid-based system for CPU cooling implementing a jet array impingement waterblock and a tube array remote heat exchanger", Appl. Therm. Eng. 39,2012, 86-94.

[15] C.J. Ho and W.C. Chen, "An experimental study on thermal performance of $\mathrm{Al}_{2} \mathrm{O}_{3} /$ water nanofluid in a minichannel heat sink”, Appl. Therm. Eng. 50, 2013, 516- 522.

[16] J.F. Tullius and Y. Bayazitoglu, "Effect of $\mathrm{Al}_{2} \mathrm{O}_{3} / \mathrm{H}_{2} \mathrm{O}$ nanofluid on MWNT circular fin structures in a minichannel", Int. J. Heat Mass Transfer 60, 2013, 523-530. 
[17] P. Naphon and L. Nakharintr, "Heat transfer of nanofluids in the mini-rectangular fin heat sinks", Int. Commun. Heat Mass Transfer 40, 2013, 25-31.

[18] M. Keshavarz Moraveji, R. Mohammadi Ardehali and A. Ijam, "CFD investigation of nanofluid effects (cooling performance and pressure drop) in mini-channel heat sink", Int. Commun. Heat Mass Transfer 40, 2013, 58-66.

[19] I. Elbadawy, S. Anbr and M. Fatouh," Heat transfer Characteristics of Water Flowing Through Single and Double Stack Rectangular Microchanels", $16^{\text {th }}$ Int. AMME Conference, Egypt, 2014

[20] S.V. Patankar, "Numerical Heat Transfer and Fluid Flow", Hemisphere, NY, 1980.

[21] W.Q. Tao,'Numerical Heat Transfer", second ed., Xi'an Jiaotong University Press, Xi'an, China, 2001.

[22] X. L. Xie, Z. J. Liu, Y. L. He and W. Q. Tao, "Numerical study of laminar heat transfer and pressure drop characteristics in a water-cooled minichannel heat sink", Applied thermal engineering, vol. 29, 2009, pp. 64-74.

[23] W. Qu and I. Mudawar, "Experimental and numerical study of pressure drop and heat transfer in a single-phase micro-channel heat sink", International Journal of Heat and Mass Transfer 45, 2002, pp. 2549-2565

[24] Jaeseon Lee and Issam Mudawar, "Assessment of the effectiveness of nanofluids for single-phase and two-phase heat transfer in micro-channels", International Journal of Heat and Mass Transfer 50, 2007, 452-463

[25] M. Amoura, M. Alloti, A. Mouassi and N. Zeraibi, "Study of Heat Transfer of Nanofluids in a Circular Tube", International Journal of Mathematical, Computational, Physical and Quantum Engineering Vol:7 No:9, 2013

[26] O. Levenspiel, "Engineering Flow and Heat Exchange" , $2^{\text {nd }}$ Edition, Plenum Press, 1998 